J. Amer. Soc. Hort. ScI. 116(3):416-420. 1991.

\title{
Growth and Yield of Tomato Plants in Response to Age of Transplants
}

\author{
Daniel I. Leskovar' and Daniel J. Cantliffe \\ Vegetable Crops Department, Institute of Food and Agricultural Science, University of Florida, \\ Gainesville, FL 32611
}

Peter J. Stoffella

Agricultural Research and Education Center, Institute of Food and Agricultural Science, University of Florida, P. O. Box 248, Fort Pierce, FL 34954

Additional index words. Lycopersicon esculentum, chlorophyll, fruit size, fruit yield, root growth, shoot growth, irrigation systems

\begin{abstract}
Studies were conducted to evaluate growth of tomato (Lycopersicon esculentum Mill.) transplants in the field in response to age of transplants in Spring and Fall 1989. Transplants were $2(2 W), 3(3 W), 4(4 W), 5(S W)$, or $6(6 \mathrm{~W})$ weeks old. Drip and subseepage irrigation were used. In spring, older transplants produced more shoot and root growth up to 2 (T2) weeks after transplanting. At 3 (T3) and 4 (T4) weeks after transplanting, there were no differences between $4 \mathrm{~W}, 5 \mathrm{~W}$, and $6 \mathrm{~W}$ transplants. These trends were independent of irrigation systems. Total yield and early yield were similar for all transplant ages. In fall, shoot growth increased linearly with increasing transplant age at TO, but not thereafter. Chlorophyll $a+b$ increased over time, but no treatment differences were found at T4. At planting, $2 \mathrm{~W}$ transplants had a higher $\mathrm{Chl}$ a : b ratio than older transplants. This difference was reduced at $\mathrm{T} 1$ and $\mathrm{T} 2$ and became insignificant at $\mathrm{T} 4$. These results indicate that no improvement in yields was obtained using the traditional older transplants. Younger transplants might be used to achieve rapid seedling establishment with-minimal transplant production costs.
\end{abstract}

In Florida, fresh-market tomatoes are established in the field by direct seeding or by using 5- or 6-week-old containerized transplants. Effects of age of containerized Transplants have been reported on several vegetable species. Lowest head weight variability was found in "lettuce using 13- and 19-day-old transplants compared to those 25 days old (Wurr and Fellows, 1986). Conversely, earlier yields were obtained from 7-week-old lettuce transplants than from those 6 to 3 weeks old (Wang and Kratky, 1976). Yields were similar for 3- to 6-week-old Chinese cabbage transplants (Kratky et al., 1982). Similarly, marketable curd yields did not differ among 5- to 8-week-old cauliflower transplants (Wurr et al., 1986). Asparagus transplants that were 8.5 weeks old produced more shoots than those 6 and 7 weeks old, and a similar number as 10-week-old transplants (Dufault and Waters, 1984). In pepper, 60-day-old seedlings had greater early yields than younger ones (Weston, 1988).

Plant growth improvement using relatively young bareroot tomato transplants has been reported (Nicklow and Minges, 1962). Weston and Zandstra (1989), using containerized transplants, reported that plant height, leaf area, and shoot weight increased linearly as transplant age increased from 3 to 6 weeks, but measurements were done only at transplanting. None of these studies considered the changes in shoot and root development after transplanting. Such information would be useful in understanding the relationship between the physiological state of transplants and their growth responses under various cultural systems and environments.

This study was conducted to determine the effects of transplant age on growth after re-establishment and on fruit size, count, and yield.

Received for publication 16 July 1990. Univ. of Florida Journal Series no. R00872. We are grateful to Speedling, Inc., for support of this research. The cost of publishing this paper was defrayed in part by the payment of page charges. Under postal regulations, this paper therefore must be hereby marked advertisement solely to indicate this fact.

'Current address: Texas Agr. Expt. Sta., Texas A\&M Univ., 1619 Garner Field Rd., Uvalde, TX 78801.

\section{Materials and Methods}

Transplant production, Spring 1989. Seedlings were grown at Speedling, Inc., in greenhouses at Bushnell, Fla. (lat. 28.4 $\mathrm{N}$ and long. $82.5 \mathrm{~W}$ ). Speedling polystyrene trays with 128 inverted pyramid cells of $3.8 \times 6.4 \mathrm{~cm}$ (side length $\mathrm{x}$ depth; $31 \mathrm{~cm}^{3}$ ) were used. Tomato seeds were sown in a 2 peat : 1 vermiculite :1 perlite mix (by volume) on 19 and 26 Dec. 1988 and on 2 and 9 Jan. 1989 to obtain 3 (3W)-, 4 (4W)-, 5 (5W)-, and $6(6 \mathrm{~W})$-week-old transplants. Trays were held in germination chambers at $25 \mathrm{C}$ and $100 \%$ relative humidity for 3 days and then in greenhouses where they remained until transplanting. After seedling emergence, transplants were irrigated using a flotation system three times/week for $45 \mathrm{~min}$ until 21 days (Leskovar et al., 1990). In each irrigation, a soluble fertilizer (2ON-1OP-2OK) was given at a concentration of $50 \mathrm{mg}$ of $\mathrm{N} /$ liter. After 21 days, seedlings $(4 \mathrm{~W}, 5 \mathrm{~W}$, and $6 \mathrm{~W})$ were irrigated twice/week for $30 \mathrm{~min}$. In the last irrigation, seedlings were watered with the same nutrient solution and rate used before. The greenhouse was held at a 28C maximum and 6C minimum.

Transplant production, Fall 1989. Seedlings were grown in Speedling polystyrene trays with 200 inverted pyramid cells of $2.5 \times 7.0 \mathrm{~cm}$ (side length $\mathrm{x}$ depth; $18 \mathrm{~cm}^{3}$ ). Tomato seeds were sown on 15, 21, and 28 July and 4 Aug. 1989 for the 2-, 3-, 4-, and 5-week-old transplants, respectively. After 5 days, seedlings were irrigated daily with a $2 \mathrm{ON}-1 \mathrm{OP}-2 \mathrm{OK}(50 \mathrm{mg}$ of N/liter) nutrient solution for 30 min until 21 days and using the same irrigation system used in Spring 1989. After 21 days, transplants $(4 \mathrm{~W}$ and $5 \mathrm{~W}$ ) were irrigated three times/week for $30 \mathrm{~min}$ and 1 day before delivery to the field with the same nutrient solution and rate used before. The greenhouse was held at a $34 \mathrm{C}$ maximum and $18 \mathrm{C}$ minimum.

Spring 1989, Expt. 1, Parri.sh. Transplants were planted at a commercial farm located in Parrish, Fla., (sandy, siliceous, hyperthermic, Entic Haplaquods) on 2 Feb. 1989. The transplants were $3(3 \mathrm{~W}), 4(4 \mathrm{~W}), 5(5 \mathrm{~W})$, or $6(6 \mathrm{~W})$ weeks old. Plants were grown on single raised (15-cm-high) beds spaced $1.8 \mathrm{~m}$ between rows and $0.6 \mathrm{~m}$ within rows. Fertilizer $(26 \mathrm{~N}-107 \mathrm{P}-$ 
Table 1. Shoot and root characteristics of tomato transplants as affected by their age, Spring 1988. Experiment 1 at Parrish, Fla., and Expt. 2 at Bradenton, F1a. ${ }^{2}$

\begin{tabular}{|c|c|c|c|c|c|c|c|c|c|}
\hline \multirow{2}{*}{$\begin{array}{c}\text { Transplant } \\
\text { age } \\
\text { (weeks) }\end{array}$} & \multicolumn{3}{|c|}{$\begin{array}{l}\text { Stem length } \\
\text { (cm) }\end{array}$} & \multicolumn{3}{|c|}{$\begin{array}{c}\text { Stem diam } \\
(\mathrm{mm})\end{array}$} & \multicolumn{3}{|c|}{$\begin{array}{c}\text { Leaf area } \\
\left(\mathrm{cm}^{2}\right)\end{array}$} \\
\hline & T0 & $\mathrm{T} 1$ & $\mathrm{~T} 2$ & TO & T1 & $\mathrm{T} 2$ & T0 & $\mathrm{T} 1$ & $\mathrm{~T} 2$ \\
\hline & \multicolumn{9}{|c|}{ Expt. 1} \\
\hline 3 & 3.9 & 6.1 & 8.3 & 1.6 & 3.3 & 4.8 & 9 & 38 & 106 \\
\hline 4 & 6.0 & 7.3 & 9.4 & 2.5 & 4.4 & 5.0 & 21 & 63 & 110 \\
\hline 5 & 7.5 & 9.4 & 12.9 & 2.6 & 4.1 & 5.3 & 26 & 62 & 204 \\
\hline 6 & 8.3 & 11.3 & 14.9 & 2.6 & 3.8 & 5.6 & 28 & 81 & 211 \\
\hline \multirow[t]{2}{*}{ Significance } & $\mathrm{Q}^{*}$ & $\mathrm{~L}^{* *}$ & $\mathrm{~L}^{* *}$ & $\mathrm{Q}^{* *}$ & $\mathrm{Q}^{*}$ & $\mathrm{~L}^{*}$ & $\mathrm{~L}^{* *}$ & $\mathrm{~L}^{* *}$ & $\mathrm{~L}^{* *}$ \\
\hline & \multicolumn{9}{|c|}{ Expt. 2} \\
\hline 3 & 3.9 & 5.8 & 7.3 & 1.6 & 3.2 & 4.3 & 9 & 33 & 64 \\
\hline 4 & 6.0 & 7.5 & 8.8 & 2.5 & 4.3 & 5.0 & 21 & 55 & 98 \\
\hline 5 & 7.5 & 9.2 & 10.9 & 2.6 & 3.8 & 4.5 & 26 & 61 & 125 \\
\hline 6 & 8.3 & 11.7 & 13.9 & 2.6 & 4.1. & 5.1 & 28 & 83 & 172 \\
\hline Significance & $\mathrm{Q}^{*}$ & $\mathrm{~L}^{* *}$ & $\mathrm{~L}^{* *}$ & $\mathrm{Q}^{* *}$ & $\mathrm{Q}^{*}$ & $\mathbf{L}^{*}$ & $\mathrm{Q}^{* *}$ & $\mathrm{~L}^{* *}$ & $\mathrm{~L}^{* *}$ \\
\hline
\end{tabular}

$42 \mathrm{~K}, \mathrm{~kg} \cdot \mathrm{ha}^{-1}$ ) was broadcast and incorporated in the center of the bed. Topdress fertilizer $\left(300 \mathrm{~N}-480 \mathrm{~K}, \mathrm{~kg} \cdot \mathrm{ha}^{-1}\right)$ was applied in two bands in shallow grooves on the bed surface $25 \mathrm{~cm}$ to each side of the bed center. Beds were fumigated with 67 methyl bromide :33 chloropicrin at $210 \mathrm{~kg} \cdot \mathrm{ha}^{-1}$ and covered with black polyethylene mulch (0.038-mm thickness). Subseepage irrigation was applied to maintain a uniform level of moisture and a water table $\approx 40 \mathrm{~cm}$ deep. Subseepage irrigation ditches were located between every four beds. Standard pesticides and cultural practices were used (Hochmuth, 1988). The monthly means after transplanting were $18.5 \mathrm{C}$ for Feb. and $21.2 \mathrm{C}$ for March.

Plants for root samples were shovel-excavated at times noted below at $20 \times 20 \mathrm{~cm}$ (side $\mathrm{x}$ side) from the center of the plant and at a 30-cm depth. Plants were first gently shaken with the shovel, grasped by the stem, placed in polyethylene bags, and transported to $5 \mathrm{C}$ rooms, where they remained for 1 to 2 days, until examined. Shoots were excised at soil surface. Stem diameter was measured with a digital caliper just below the cotyledonary node. Stem length was measured from the shoot apex to the cut end and leaf area (LA) with a LI-COR (Model LI3100; LI-COR, Lincoln, Neb.) leaf area meter. Soil was washed from the roots, and roots collected from the medium from a 1-

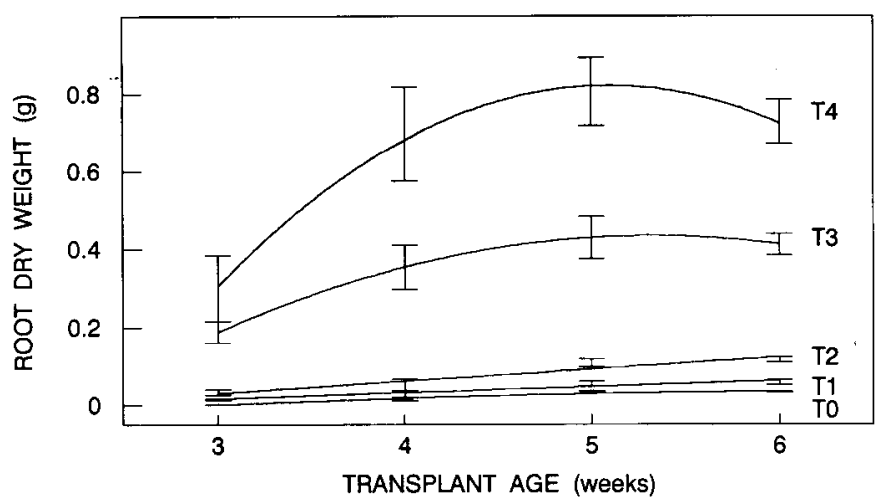

Fig. 1. Root dry weight as affected by transplant age. Spring 1989, Expt. 1, Parrish, Fla. Transplant age effects were linear (L) or quadratic (Q) at time of planting (TO) and 1 (Tl), 2 (T2), 3 (T3), and 4 (T4) weeks after transplanting. Vertical bars represent \pm SE. TO $\left(\mathrm{Q}, \mathrm{r}^{2}=82\right), \mathrm{T} 1\left(\mathrm{~L}, \mathrm{r}^{2}=75\right), \mathrm{T} 2\left(\mathrm{~L}, \mathrm{r}^{2}=78\right), \mathrm{T} 3\left(\mathrm{Q}, \mathrm{r}^{2}=70\right)$, and $\mathrm{T} 4\left(\mathrm{Q}, \mathrm{r}^{2}=70\right)$. $\mathrm{mm}^{2}$ mesh screen. Each type of plant material was oven-dried separately at $65 \mathrm{C}$ for 3 days, and dry weight of leaves (LDW), stems, and roots were recorded. Shoot : root ratios (S: R), specific leaf area (SLA $=\mathrm{LA} / \mathrm{LDW})$, and relative growth rates (RGR) were calculated (Hunt, 1982). Fruits were harvested at the mature-green stage from 10 plants per replication at 89, 104, and 124 days after transplanting, respectively. Fruits were graded (U.S. Dept. of Agriculture, 1976) into large $(65-70 \mathrm{~mm}$ in diameter) and extra large (>70 $\mathrm{mm}$ in diameter) sizes, counted, and weighed. Since the field environment was considered near optimum for plant growth, medium (57-65 $\mathrm{mm}$ in diameter) fruits were left on the plants for further growth.

A randomized complete block design with four replications for each treatment was used. Plants were sampled (two per replication) destructively at $\mathrm{O}, 7,14,21$, and 28 days after planting. Effects of transplant age were partitioned into linear or quadratic orthogonal responses. Data for leaf, stem, and root growth (dry weight) were analyzed by polynomial regression (SAS Institute, Cary, N.C.). Fruit yield data were subjected to analysis of variance and orthogonal contrasts. Means were separated by LSD (0.05).

Table 2. Influence of transplant age on the mean relative growth rate (RGR) following transplanting, Spring 1988. Experiment 1 at Parrish. Fla., and Expt. 2 at Bradenton, Fla. ${ }^{2}$

\begin{tabular}{|c|c|c|c|c|}
\hline \multirow{2}{*}{$\begin{array}{c}\text { Transplant } \\
\text { age } \\
\text { (weeks) }\end{array}$} & \multicolumn{4}{|c|}{$\operatorname{RGR}\left(\mathrm{g} \cdot \mathrm{g}^{-1} \cdot\right.$ day $\left.^{-1}\right)$} \\
\hline & T0-T1 & $\mathrm{T} 1-\mathrm{T} 2$ & $\mathrm{~T} 2-\mathrm{T} 3$ & T3-T4 \\
\hline & \multicolumn{4}{|c|}{ Expt. 1} \\
\hline 3 & 0.112 & 0.069 & 0.089 & 0.034 \\
\hline 4 & 0.103 & 0.040 & 0.125 & 0.042 \\
\hline 5 & 0.067 & 0.067 & 0.094 & 0.040 \\
\hline 6 & 0.061 & 0.063 & 0.084 & 0.036 \\
\hline \multirow[t]{2}{*}{ LSD $(0.05)$} & 0.026 & $\cdots$ & 0.032 & --- \\
\hline & \multicolumn{4}{|c|}{ Expt. 2} \\
\hline 3 & 0.105 & 0.054 & 0.098 & --- \\
\hline 4 & 0.086 & 0.040 & 0.099 & --- \\
\hline 5 & 0.044 & 0.051 & 0.100 & --- \\
\hline 6 & 0.066 & 0.049 & 0.081 & --- \\
\hline LSD $(0.05)$ & 0.020 & $\cdots$ & --- & --- \\
\hline
\end{tabular}

${ }^{z} \mathrm{~T} 0-\mathrm{T} 1, \mathrm{~T} 1-\mathrm{T} 2, \mathrm{~T} 2-\mathrm{T} 3$, and T3-T4 are weekly time intervals after 
Table 3. Effects of transplant age on yield and fruit count for the early and all harvests (Expt. 1, Parrish, Fla., Spring 1989).

\begin{tabular}{|c|c|c|c|c|c|c|}
\hline \multirow{2}{*}{$\begin{array}{c}\text { Transplant } \\
\text { age } \\
\text { (weeks) }\end{array}$} & \multicolumn{3}{|c|}{ Early harvest } & \multicolumn{3}{|c|}{ All harvests } \\
\hline & Large & $\begin{array}{l}\text { Extra } \\
\text { large }\end{array}$ & Total & Large & $\begin{array}{l}\text { Extra } \\
\text { large }\end{array}$ & Total \\
\hline & \multicolumn{6}{|c|}{ Yield $\left(t \cdot h a^{-1}\right)$} \\
\hline 3 & 14.3 & 14.0 & 28.2 & 60.7 & 32.0 & 92.7 \\
\hline 4 & 18.4 & 17.2 & 35.6 & 71.2 & 32.7 & 103.9 \\
\hline 5 & 20.4 & 21.2 & 41.5 & 63.7 & 39.2 & 102.9 \\
\hline 6 & 13.8 & 16.4 & 30.2 & 56.8 & 31.5 & 88.3 \\
\hline Significance & $\mathrm{Q}^{*}$ & NS & $\mathrm{Q}^{*}$ & $\mathrm{Q}^{*}$ & NS & $\mathrm{Q}^{*}$ \\
\hline \multirow[t]{2}{*}{$\operatorname{LSD}(0.05)$} & 4.8 & $\ldots$ & -- & 12.2 & -- & $\ldots$ \\
\hline & \multicolumn{6}{|c|}{ Fruit/plant (no.) } \\
\hline 3 & 13.3 & 9.1 & 22.4 & 52.3 & 20.5 & 72.7 \\
\hline 4 & 17.3 & 10.9 & 28.2 & 62.1 & 20.5 & 82.7 \\
\hline 5 & 19.3 & 13.6 & 32.9 & 56.6 & 25.1 & 81.7 \\
\hline 6 & 13.0 & 10.6 & 23.6 & 48.7 & 20.1 & 68.8 \\
\hline Significance & $\mathrm{Q}^{*}$ & NS & $\mathrm{Q}^{*}$ & $\mathrm{Q}^{* *}$ & NS & $\mathrm{Q}^{*}$ \\
\hline
\end{tabular}

Spring 1989, Expt. 2, Bradenton. Transplants were set at a commercial farm in Bradenton, Fla., (sandy, siliceous, hyperthermic, Alfic Haplaquods) on 2 Feb. 1989. The transplants were $3(3 \mathrm{~W}), 4(4 \mathrm{~W}), 5(5 \mathrm{~W})$, or $6(6 \mathrm{~W})$ weeks old. Plants were grown on single raised $(20 \mathrm{~cm})$ beds covered with black polyethylene mulch. The plants were spaced $1.8 \mathrm{~m}$ between rows and $0.5 \mathrm{~m}$ within rows. Preplant $\left(39 \mathrm{~N}-100 \mathrm{P}-62 \mathrm{~K}, \mathrm{~kg} \cdot \mathrm{ha}^{-1}\right)$ and topdress fertilizer $\left(216-311 \mathrm{~K}, \mathrm{~kg} \cdot \mathrm{ha}^{-1}\right)$ were applied as for Expt. 1. Drip tubing (Netafim, Altamonte Springs, Fla.) was positioned $15 \mathrm{~cm}$ deep and $25 \mathrm{~cm}$ to the sides of the plants. Drippers were spaced $60 \mathrm{~cm}$ apart with a drip discharge of 2.25 liters $\cdot \mathrm{h}^{-1}$. Irrigation kept the water table at $50 \mathrm{~cm}$ from the top of the bed. Fumigation was done as in Expt. 1. Plant sampling was initiated at transplanting until 21 days thereafter (DAT). A late freeze in Feb. killed these plants; thus, no yields were obtained. Growth measurements and data analysis were as in Expt. 1.

Fall 1989, Expt. 3, Parrish. Transplants were set on 17 Aug. 1989 in Parrish, Fla., in the same field as of Expt. 1. The transplant ages were $2(2 \mathrm{~W}), 3(3 \mathrm{~W}), 4(4 \mathrm{~W})$, or $5(5 \mathrm{~W})$ weeks.
Cultural practices were the same as described for Expt. 1, except that within-row plant spacing was $0.75 \mathrm{~m}$ and beds were mulched with white polyethylene mulch. Plant sampling was done at 0 , 7,14 , and 21 days after planting. The monthly means after transplanting were 28.6C for August and 27.9C for September. Medium, large, and extra-large fruits were harvested at 75, 90, and 109 days after transplanting. Growth measurements and data analysis were the same as described above.

Fall 1989, Expt. 4, Bradenton. Transplants were set on 17 Aug. 1989 in Bradenton, Fla., in the same field as Expt. 2. The transplant ages were $2(2 \mathrm{~W}), 3(3 \mathrm{~W}), 4(4 \mathrm{~W})$, or $5(5 \mathrm{~W})$ weeks. All experimental and cultural practices were the same as for Expt. 2. The monthly means after transplanting were $28.3 \mathrm{C}$ for August and 27.7C for September. Chlorophyll (Chl) content on the newest fully expanded leaflet (>2 cm long) was determined (Arnon, 1949). Measurements were performed in a UV/VIS spectrophotometer (Lambda 3A; Perkin-Elmer, Norwalk, Corm.) at 663,652 , and $645 \mathrm{~nm}$; Chl a, b, and $\mathrm{a}+\mathrm{b}$ in milligrams per gram fresh weight $(\mathrm{FW})$ was determined, and $\mathrm{Chl} a \mathrm{a}$ ratio calculated. Samplings, growth measurements, and data analysis were conducted as before.

\section{Results and Discussion}

Spring 1989. Stem length and leaf area increased linearly with increasing transplant age at 1 (T1) and 2 (T2) weeks after transplanting (Table 1). At $\mathrm{T} 1$ and $\mathrm{T} 2,5 \mathrm{~W}$ and $6 \mathrm{~W}$ transplants had greater root dry weights than $3 \mathrm{~W}$ and $4 \mathrm{~W}$ transplants; however, at T3 and T4, dry weights were not significantly different among $4 \mathrm{~W}, 5 \mathrm{~W}$, and $6 \mathrm{~W}$ transplants (Fig. 1). Similar responses were observed for leaf and stem dry weight increase. Initially, after transplanting, $3 \mathrm{~W}$ and $4 \mathrm{~W}$ transplants had higher RGR and thus greater capacity to resume growth than older transplants (Table 2 ). The low RGR values during the 2 nd week of growth were probably due to low mean temperatures (maximum/minimum, 23/9C). Between 2 and 3 weeks, $4 \mathrm{~W}$ transplants had a higher

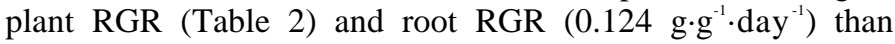
6W (0.078) transplants.

During seedling culture, older transplants may be exposed to more water and fertilizer stress than younger transplants. Widders (1989) emphasized the importance of increasing the seedling nutrient content to enhance growth after field planting.

Table 4. Shoot characteristics of tomato transplants as affected by age, Fall 1989. Experiment 3 at Parrish, Fla., and Expt. 4 at Bradenton, Fla. ${ }^{z}$

\begin{tabular}{|c|c|c|c|c|c|c|c|c|c|}
\hline \multirow{2}{*}{$\begin{array}{c}\text { Transplant } \\
\text { age } \\
\text { (weeks) }\end{array}$} & \multicolumn{3}{|c|}{$\begin{array}{l}\text { Stem length } \\
(\mathrm{cm})\end{array}$} & \multicolumn{3}{|c|}{$\begin{array}{l}\text { Stem diam } \\
(\mathrm{mm})\end{array}$} & \multicolumn{3}{|c|}{$\begin{array}{l}\text { Leaf area } \\
\left(\mathrm{cm}^{2}\right)\end{array}$} \\
\hline & T0 & $\mathrm{T} 1$ & $\mathrm{~T} 2$ & T0 & $\mathrm{T} 1$ & $\mathrm{~T} 2$ & TO & $\mathrm{T} 1$ & $\overline{\mathrm{T} 2}$ \\
\hline & \multicolumn{9}{|c|}{ Expt. 3} \\
\hline 2 & 4.2 & 7.8 & 11.0 & 1.6 & 3.5 & 8.4 & 6 & 27 & 200 \\
\hline 3 & 5.5 & 8.1 & 11.2 & 2.1 & 3.2 & 8.5 & 10 & 40 & 203 \\
\hline 4 & 8.3 & 9.6 & 15.7 & 2.6 & 3.8 & 8.6 & 21 & 41 & 390 \\
\hline 5 & 13.1 & 11.5 & 15.6 & 2.9 & 3.7 & 7.4 & 30 & 30 & 195 \\
\hline Significance & $\mathrm{Q}^{* *}$ & $\mathrm{~L}^{* *}$ & $\mathrm{~L}^{* *}$ & $\mathrm{~L}^{* *}$ & NS & NS & $\mathrm{L}^{* *}$ & $\mathrm{Q}^{*}$ & NS \\
\hline \multirow[t]{2}{*}{ LSD $(0.05)$} & 0.8 & 1.8 & 3.0 & 0.2 & -- & -- & 4 & -- & -- \\
\hline & \multicolumn{9}{|c|}{ Expt. 4} \\
\hline 2 & 4.2 & 6.9 & 11.3 & 1.6 & 2.8 & 4.3 & 6 & 20 & 122 \\
\hline 3 & 5.5 & 7.3 & 9.2 & 2.1 & 3.2 & 3.8 & 10 & 26 & 73 \\
\hline 4 & 8.3 & 9.5 & 12.9 & 2.6 & 3.7 & 4.6 & 21 & 38 & 114 \\
\hline 5 & 13.1 & 13.3 & 16.7 & 2.9 & 3.5 & 4.5 & 30 & 52 & 174 \\
\hline Significance & $\mathrm{Q}^{* *}$ & $\mathrm{Q}^{*}$ & $\mathrm{Q}^{*}$ & $\mathrm{~L}^{* *}$ & $\mathrm{~L}^{*}$ & NS & $\mathrm{L}^{* *}$ & $\mathrm{~L}^{* *}$ & NS \\
\hline
\end{tabular}

${ }^{z} \mathrm{~T} 0=$ at transplanting; $\mathrm{T} 1$ and $\mathrm{T} 2$ are 1 and 2 weeks after transplanting.

NS,*,**Nonsignificant or significant $F$ test at $P=0.05$ or 0.01 , respectively. Transplant age effect was linear (L) or quadratic (Q). 
Table 5. Effects of transplant age on yield and fruit number for the early and all harvests (Expt. 3, Parrish, Fla., Fall 1989).

\begin{tabular}{|c|c|c|c|c|c|c|c|}
\hline \multirow{2}{*}{$\begin{array}{c}\text { Transplant } \\
\text { age } \\
\text { (weeks) }\end{array}$} & \multicolumn{3}{|c|}{ Early harvest } & \multicolumn{4}{|c|}{ Total harvests } \\
\hline & Large & $\begin{array}{l}\text { Extra } \\
\text { large }\end{array}$ & Total & Medium & Large & $\begin{array}{l}\text { Extra } \\
\text { large }\end{array}$ & Total \\
\hline & \multicolumn{7}{|c|}{ Yield $\left(t \cdot h a^{-1}\right)$} \\
\hline 2 & 5.1 & 5.8 & 10.9 & 5.1 & 26.7 & 12.5 & 44.3 \\
\hline 3 & 7.7 & 5.3 & 13.0 & 7.9 & 30.4 & 10.5 & 48.9 \\
\hline 4 & 5.7 & 7.7 & 13.4 & 5.8 & 27.2 & 14.4 & 47.5 \\
\hline 5 & 6.1 & 2.9 & 8.9 & 6.1 & 28.1 & 8.8 & 42.4 \\
\hline \multirow[t]{2}{*}{ Significance } & NS & NS & NS & NS & NS & NS & NS \\
\hline & \multicolumn{7}{|c|}{ Fruit/plant (no.) } \\
\hline 2 & 5.8 & 4.4 & 10.2 & 7.4 & 29.3 & 9.6 & 46.2 \\
\hline 3 & 8.6 & 4.2 & 12.9 & 11.3 & 33.8 & 8.7 & 53.8 \\
\hline 4 & 6.0 & 6.7 & 12.7 & 8.3 & 29.5 & 12.2 & 50.0 \\
\hline 5 & 7.0 & 2.3 & 9.4 & 8.6 & 31.2 & 6.5 & 46.3 \\
\hline Significance & NS & NS & NS & NS & NS & NS & NS \\
\hline
\end{tabular}

NSNonsignificant F test.

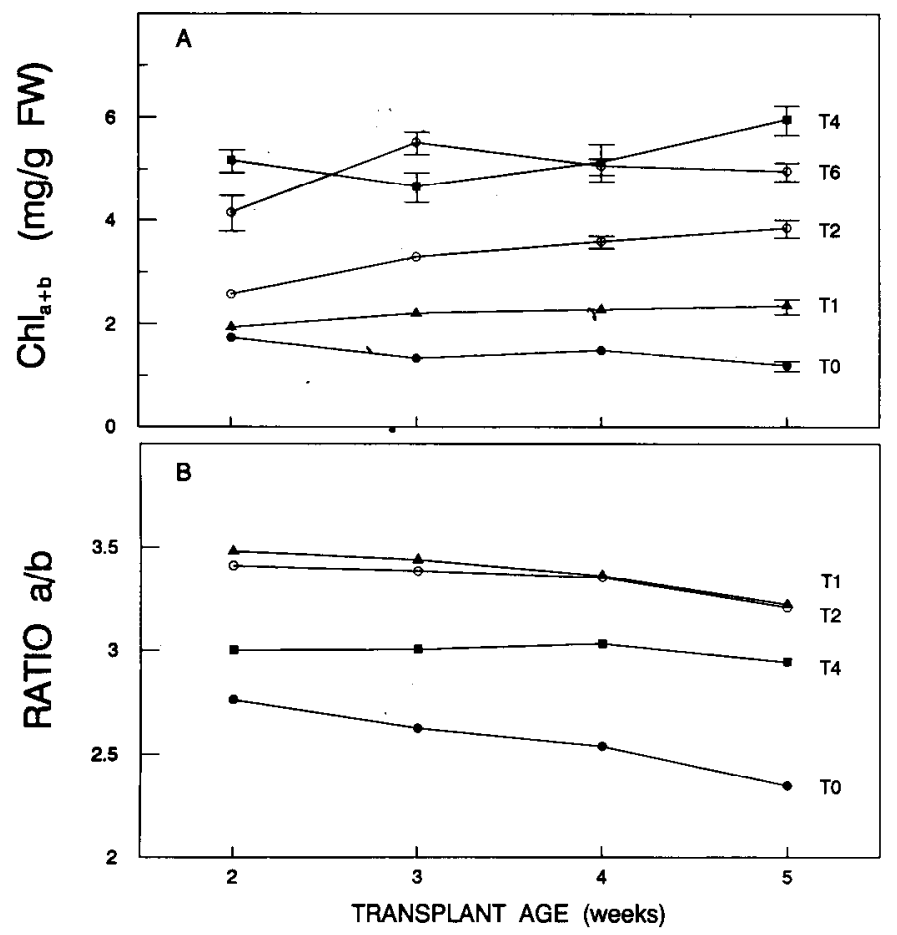

Fig. 2. Total chlorophyll $(\mathrm{Chl}) \mathrm{a}+\mathrm{b}(\mathbf{A})$ and chlorophyll $\mathrm{a}: \mathrm{b}$ ratio (B) as affected by transplant age at time of planting (TO) and 1 (Tl), 2 (T2), 4 (T4), and 6 (T6) weeks after transplanting.

Nutrient deficiency and dehydration have been reported to decrease the permeability of roots, possibly due to suberization of the cell walls (Passioura, 1988).

Early total and total (pooled harvests) fruit yields were similar for all transplant ages (Table 3). Five-week-old transplants had $47 \%$ more early large fruit, and $4 \mathrm{~W}$ transplants $25 \%$ more total large fruit yield than $6 \mathrm{~W}$ transplants (Table 3). Therefore, the growth advantages of younger ( $3 \mathrm{~W}$ and $4 \mathrm{~W})$ transplants were eventually translated into similar or higher yields of large fruit. However, Weston and Zandstra (1989) reported that total marketable yield for $3 \mathrm{~W}, 4 \mathrm{~W}, 5 \mathrm{~W}$, and $6 \mathrm{~W}$ transplants grown under sprinkler irrigation increased linearly with increasing transplant age.

Spring 1989. Most of the root and shoot characteristics followed the same trend as in the first experiment (Table 1), but higher growth rate values for younger transplants ( $3 \mathrm{~W}$ and $4 \mathrm{~W}$ ) were found only during the first week of growth (Table 2).

Fall 1989. Transplants that were 4 or 5 weeks old had significantly longer stems than $2 \mathrm{~W}$ and $3 \mathrm{~W}$ plants (Table 4 ). At T0, leaf area increased linearly with increasing transplant age from $2 \mathrm{~W}$ to $5 \mathrm{~W}$; however, these differences were minimal at T1. Similarly, at T0, leaf, stem, and root dry weights increased linearly with increasing transplant age, but these differences were not observed thereafter (data not presented).

Early total and total marketable fruit yields were similar among treatments (Table 5) and trends did not depend on transplant age. Larger early fruit yields were found for 5-week-old bareroot transplants than for 7- or 9-week-old transplants (Nicklow and Minges, 1962).

Fall 1989. Chl $\mathrm{a}+\mathrm{b}\left(\mathrm{mg} \cdot \mathrm{g}^{-1} \mathrm{FW}\right)$ of the transplants increased through 4 weeks after transplanting (Fig. 2A). At T0, $\mathrm{Chl} \mathrm{a}+\mathrm{b}$ for $2 \mathrm{~W}$ seedlings was 1.736 (SE \pm 0.082 ), $44 \%$ and $17 \%$ higher than that of the $5 \mathrm{~W}$ and $4 \mathrm{~W}$ seedlings, respectively. Lower values for older transplants at T0 may have been due to reduced light interception resulting from plant competition in the container. At T0, the leaf area index was 4.8 for $5 \mathrm{~W}$ compared to 1.0 for $2 \mathrm{~W}$ plants. At T1 and T2, older transplants had more $\mathrm{Chl} \mathrm{a}+\mathrm{b}$ than younger transplants. Later, this difference became nonsignificant. At T0, the Chl a : b ratio for the $2 \mathrm{~W}$ seedling was significantly higher (2.8) than that for older transplants (2.4), a difference that was less evident at T1 and T2, and insignificant at T4. In many plant species, $\mathrm{Chl} \mathrm{a}: \mathrm{b}$ values of 2.5 to 2.9 have been reported for shade leaves, and values of 3 to 3.5 are characteristic for sun-exposed leaves (Czeczuga, 1987). Therefore, the ratio of Chl a to $\mathrm{b}$ was modified by growth conditions and environmental factors, such as light (Lichtenthaler, 1987).

SLA at transplanting was 0.436 (SE \pm 0.021$), 0.331( \pm 0.011)$, $0.274( \pm 0.007)$, and $0.255( \pm 0.007) \mathrm{cm}^{2} \cdot \mathrm{mg}^{-1}$ for $2 \mathrm{~W}, 3 \mathrm{~W}$, $4 \mathrm{~W}$, and SW transplants, respectively. The high SLA in young transplants indicated that their leaves, still in the process of extension, were thinner than the thicker, smaller leaves of older transplants. SLA decreased at $\mathrm{T} 1$, and at $\mathrm{T} 2$, values were not significantly different and ranged from 0.173 to $0.187 \mathrm{~cm}^{2} \cdot \mathrm{mg}^{-1}$ for $5 \mathrm{~W}$ and $2 \mathrm{~W}$, respectively. We suggest that younger transplants, with initially higher $\mathrm{Chl} \mathrm{a}+\mathrm{b}, \mathrm{Chl} \mathrm{a}: \mathrm{b}$ ratios, SLA values, and RGR, had a more efficient photosynthetic system than older transplants. 
The increase in stem diameter and leaf area with increase in transplant age stopped after T1 (Table 4). Fruit yield, fruit size, and fruit count were not significantly different among treatments for early or all harvests. Total yields $\left(\mathrm{t} \cdot \mathrm{ha}^{-1}\right)$ were 43.6 for $2 \mathrm{~W}$, 44.5 for $3 \mathrm{~W}, 45.5$ for $4 \mathrm{~W}$, and 46.8 for $5 \mathrm{~W}$ transplants. The lack of fruit yield differences between $2 \mathrm{~W}$ to $5 \mathrm{~W}$ transplants indicates that there were no advantages to using $5 \mathrm{~W}$ transplants.

In conclusion, the initial favorable transplant growth characteristics acquired while growing in the greenhouse, most evident for older transplants, were modified in the field under subseepage or drip irrigation. Transplants that were 4 weeks old in fall and 5 weeks old in spring had similar or higher yields than older transplants. These results suggest that no improvement in fruit yield is to be expected using the traditional $5 \mathrm{~W}$ and $6 \mathrm{~W}$ transplant compared to younger transplants. Use of younger transplants offers the advantage of rapid seedling establishment with minimal transplant production costs.

\section{Literature Cited}

Arnon, D.L. 1949. Cooper enzymes in isolated chloroplast polyphenoloxidase in Beta vulgaris. Plant Physiol. 24:1-6.

Czeczuga, B. 1987. Carotenoid contents in leaves grown under various light intensities. Biochem. Systematic\& Ecol. 15:523-527.

Dufault, R.J, and L. Waters. 1984. Propagation methods influence asparagus transplant quality and seedling growth. HortScience 19:866868.

Hochmuth, G.J. (cd.). 1988. Tomato production guide for Florida. Florida Coop. Ext. Serv., Inst. Food \& Agr. Sci., Univ. of Florida Circ. C98.

Hunt, R. 1982. Plant growth curves. The functional approach to plant growth analysis. Edward Arnold, London.

Kratky, B. A., J.K. Wang, and K. Kubojiri. 1982. Effects of container size, transplant age, and plant spacing on Chinese cabbage. J. Amer. Sot. Hort. Sci. 107:345-347.

Leskovar, D. I., D.J. Cantliffe, and P.J. Stoffella. 1990. Root growth and root-shoot interaction of transplants and direct seeded pepper plants. Env. Expt. Bet. 30;349-354.

Lichtenthaler, H.K. 1987. Chlorophylls and carotenoids: Pigments of photosynthetic biomembranes. Methods in Enzymology 148:350374.

Nicklow, C.W. and P.A. Minges. 1962. Plant growing factors influencing the field performance of the Fireball tomato variety. Proc. Amer. Soc. Hort. Sci. 81:443-450.

Passioura, J.B. 1988. Water transport in and to roots. Ann. Rev. Plant Physiol. Plant Molec. Biol. 39:245-265.

U.S. Department of Agriculture. 1976. United States standards for grades of fresh tomatoes. U.S. Dept. Agr., Agr. Res. Serv., Washington, D.C.

Wang, J.K. and B. Kratky. 1976. Seedling transplant and its effects on mechanized greenhouse lettuce production. Trans. Amer. Sot. Agr. Eng. p. 661-663.

326Weston, L.A. 1988. Effect of flat cell size, transplant age, and production site on growth and yield of pepper transplants. HortScience 23:704-711.

Weston, L.A. and B.H. Zandstra. 1989. Transplant age and $\mathrm{N}$ and $\mathrm{P}$ nutrition effects on growth and yield of tomatoes. HortScience 24:8890.

Widders, I.E. 1989. Pretransplant treatment of $\mathrm{N}$ and P influence growth and elemental accumulation in tomato seedlings. J. Amer. Soc. Hort. Sci. 114:416-420.

Wurr, D.C.E. and J.R. Fellows. 1986. The influence of transplant age and raising conditions on the growth of crisp lettuce plants raised in Techniculture plugs. J. Hort. Sci. 61:81-87.

Wurr, D. C. E., E.F. Cox, and J.R. Fellows. 1986. The influence of transplant age and nutrient feeding regime on cauliflower growth and maturity. J. Hort. Sci. 61:503-508. 